\title{
GSIM Measurement of the Effects of the EU accession of the Balkans and Turkey on Agricultural Trade
}

Mario Holzner*

\section{Abstract:}

In this paper, the global simulation model (GSIM) for the analysis of global, regional, and unilateral trade policy changes by Francois and Hall (2003) was applied to the agricultural trade between the EU, the Balkans and Turkey. This was done in order to measure the effects of an EU accession of the Balkans and Turkey. Most of the changes in welfare after a full liberalisation of agricultural trade between the Balkans and Turkey on the one hand and the EU on the other hand can be expected in the accession countries themselves. It is estimated that incumbent EU members will be affected only to a minor extent. It was also estimated that the exchange rate risk is not very high.

Keywords: Trade Policy Modelling, Southeast Europe, Turkey, EU Integration, Trade in Agriculture, Real Exchange Rate

JEL: F15, F17, F31, Q17
DOI: 10.2478/v10033-008-0001-0

\section{Introduction}

The aim of this study is to analyse the effects of a potential EU accession of all the Southeast European countries (SEECS) and Turkey on agricultural trade with the incumbent EU member countries and Austria in particular. The study is financed by the Federal Ministry of Agriculture, Forestry, Environment and Water Management of the Republic of Austria. The effects of a full trade liberalisation of both processed and unprocessed agricultural goods shall be measured using the global simulation model (GSIM). The model estimates trade effects, welfare effectsz (producer surplus, consumer surplus and change in tariff revenue) and price and output changes. Also, the impact of a real exchange rate distortion on agricultural trade shall be analysed. Here we focus specifically on Turkey, as all the other Balkan countries have a de facto fixed exchange rate vis $a$ vis the euro, a currency board, have even taken over the euro as legal tender, or will enter the European Exchange Rate Mechanism soon. Apart from falling trade barriers, 'beggar-my-neighbour' exchange rate policy is often considered as a threat.
The study is based on earlier, similar research done on the measurement of the costs of protection and real exchange rate distortion in Southeast Europe (see Holzner $2004,2006 a, 2006$ b) as well as analysis of the development of Central and East European agriculture in an EU context (see Lukas and Pöschl, 2003).

\section{The Model}

The model that will be applied in this study is the global simulation model (GSIM) for the analysis of global, regional,

\section{*Holzner:}

The Vienna Institute for

International Economic Studies (WIIW)

Oppolzergasse 6, 1010 Wien, Austria

e-mail: Holzner@wiiw.ac.at 
and unilateral trade policy changes by Francois and Hall (2003)'. The model is a multi-region, imperfect substitute model of world trade, employing a partial equilibrium approach.

Using a fully-fledged general equilibrium model (which would have to include a full endogenisation of income and expenditure levels across the region) would be too ambitious a task for this project, especially given the short period since the Balkans have settled into an economic region without major military-political conflicts that had serious impacts on data availability and behavioural stability. However, the partial equilibrium approach implies also some useful advantages because it allows for a relatively rapid and transparent analysis of a wide range of commercial policy issues with a minimum of data and computational requirements. In any case, a general equilibrium model does not seem to be useful as the Balkans lack proper and necessary input-output tables.

Having the limitations of the partial equilibrium approach in mind, useful insights can be drawn with regard to relatively complex, multi-country trade policy changes at the industry level. The results of the GSIM allow the assessment of importer and exporter effects related to tariff revenues, exporter (producer) surplus, and importer (consumer) surplus.

The model requires the input of a bilateral trade matrix at world prices, an initial matrix of bilateral import tariffs and export subsidies in ad valorem form, a final matrix of bilateral import tariffs and export subsidies in ad valorem form, export supply elasticities, aggregate import demand elasticities and elasticities of substitution. Using additional data, domestic production subsidy effects can also be fit into the framework. For a more detailed description of the model see Francois and Hall (2003).

\section{The Data}

The data necessary to run the GSIM model is thus detailed tariff ${ }^{2}$ (as well as data on subsidies) and trade data (including data for trade with self, i.e. sales in the domestic market) as well as estimates of demand, supply and substitution elasticities. In our model we want to estimate the effects of trade policy changes in agricultural trade on the following world regions and countries: Austria, EU-14 ${ }^{3}$, New Member States (NMS) ${ }^{4}$, East Balkan Countries (EBC) ${ }^{5}$,

\footnotetext{
1 The GSIM model can be downloaded, implemented in an Excel spreadsheet, from Joseph Francois' Homepage at: http://www.intereconomics.com/handbook/ Models/Index.htm

2 Data is trade weighted.

3 Pre-2004 EU member states, excluding Austria.

4 Ten countries that acceded the EU in May 2004

5 Romania and Bulgaria joined the EU in January 2007.
}

West Balkan Countries (WBC) ${ }^{6}$, Turkey and the Rest of the world (ROW). Moreover we want to focus our analysis on both unprocessed and processed agricultural goods.

All the necessary data was taken from the Global Trade Analysis Project (GTAP) database, Version 6.2. The original data represents the situation in the year 2001. However in order to achieve a current ('2006') base year data set we simulated in the first step the EU accession of ten new member states (NMS). The results of this simulation are used as a base for the modelling of the EU accession of the Balkans and Turkey.

The export supply elasticity (1.5), aggregate import demand elasticity (-1.25) and the elasticity of substitution (5) were adopted from Francois and Hall (2003). However, in the case of the EU-14 and the ROW an 'infinite' export supply elasticity (100) was assumed. This flattens out the supply curves and is in line with a small vs. large country assumption.

These are certainly very simplified assumptions. However, due to scarce data it would be almost impossible to estimate'true' elasticities. It could be thought of employing average elasticities as e.g. described in 22 industry studies by Messerlin (2001). There especially the elasticities of substitution seem to be in general much lower than 5 . However, in the literature an elasticity of substitution of 5 is used quite often (see also Fujita, Krugman and Venables 2000).

\section{The Results}

After feeding the model step by step with the initial bilateral trade matrix (including trade with self), at world prices, the initial matrix of bilateral importtariffs and export subsidies in ad valorem form, the final matrix of bilateral import tariffs and export subsidies in ad valorem form, as well as the production subsidies and the elasticities, the following output is estimated: trade effects, welfare effects (producer surplus, consumer surplus and change in tariff revenue) and price and output changes. This task was done for processed and unprocessed agricultural goods separately. A full liberalisation of trade between the Balkans, Turkey and the EU countries was assumed. West and East Balkan countries and Turkey are assumed to take over the EU's trade protection measures against the rest of the world. Trade protection of the rest of the world against the Balkans and Turkey was assumed to change to the current level of protection vis a vis the EU. In short this can be called a 'year 2020 scenario'. We also analyse agricultural trade in a scenario where Turkey is assumed to devalue its real exchange rate by $10 \%$, while the other Balkan countries have a fixed exchange

6 Albania, Bosnia and Herzegovina, Croatia, Macedonia, Montenegro, Serbia. 
rate regime against the EU. We will deal with these two scenarios separately.

\subsection{EU accession scenario ' 2020 '}

In this simulation we compare the situation before the accession of Romania and Bulgaria with a hypothetical situation where all the Balkan countries as well as Turkey became members of the EU. We model for unprocessed as well as processed agricultural goods trade.

According to our results a big southeastern EU accession would generally have positive net welfare effects in the unprocessed agricultural sector of all countries and regions involved (see Table 1). Gains for the incumbent EU members (Austria, EU 14, NMS) appear to be rather
EU members would face a marginal decrease of $0.1 \%$ to $0.2 \%$. On the other hand, it is estimated that the acceding countries could increase their output quite strongly. The output of unprocessed agricultural goods in the WBC region could expand by a quarter, and that of the EBC and Turkey by about $20 \%$ and $10 \%$ respectively.

Apart from some increase in trade flows across regions, the major source of the estimated output increases in the Balkans and Turkey is a strong surge in trade with themselves. This is due to several reasons. On the one hand, trade liberalisation leads to a general fall in the overall consumer prices due to cheaper imports, but also via competition due to a fall in the price of domestic products (at least in the case of the EBC and Turkey). This, in turn, leads to an increase in domestic demand. On

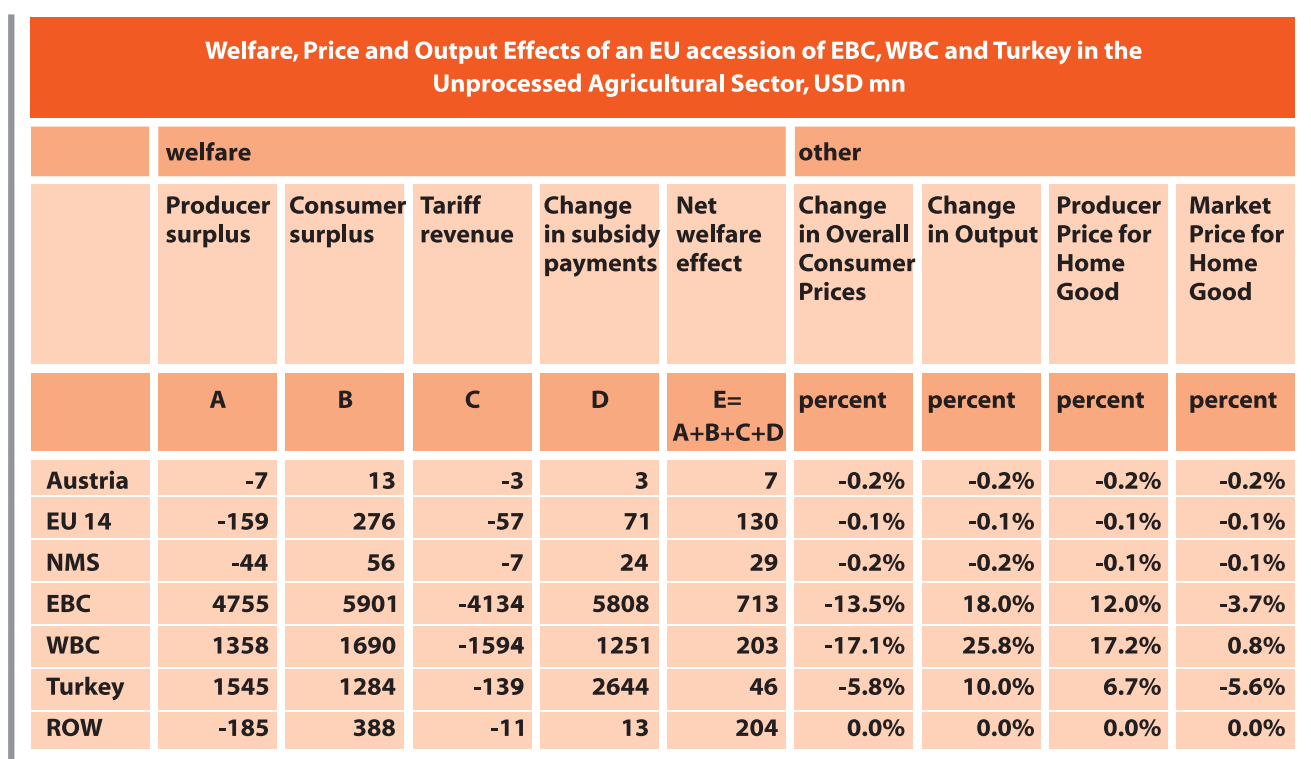

Table 1

modest. Romania and Bulgaria (EBC) would profit most in the medium and long run. Their net welfare gain would make about $700 \mathrm{mn}$ USD. This is even assuming that the high EU subsidies would be borne by themselves. Given that the EU subsidies scheme does not change by that time, the EBC unprocessed agricultural sector would be subsidised by close to 6 bn USD. The WBC net welfare gains are at around $200 \mathrm{mn}$ USD and those of Turkey close to $50 \mathrm{mn}$ USD. These stem from strong gains both in consumer and producer surpluses, which are caused falling overall consumer prices due to the annulment of tariffs and a heavy increase in producer and export subsidies.

The effects for the incumbent EU members are negligible. Austria, for instance, would have a net welfare gain of $7 \mathrm{mn}$ USD. In terms of change in output, the old the other hand, domestic producer prices do not fall but rather increase, given that the EU production and export subsidies scheme is applied in the Balkans and Turkey as well. Thus producers do not reduce their output but increase it.

Table 2 shows the resulting trade matrix after the EU accession of the Balkans and Turkey in the unprocessed agricultural sector. In the upper part the real percentage change of trade quantities is presented, while in the lower part the change in values of trade at world market prices in USD $\mathrm{mn}$ is shown. It can be observed that especially Bulgaria and Romania (EBC) as well as Turkey are able to increase their inter- and intra-regional exports after accession to quite an extent, at least in relative terms. In absolute terms, the figures seem to be less impressive. A major change in absolute values is found in trade with 


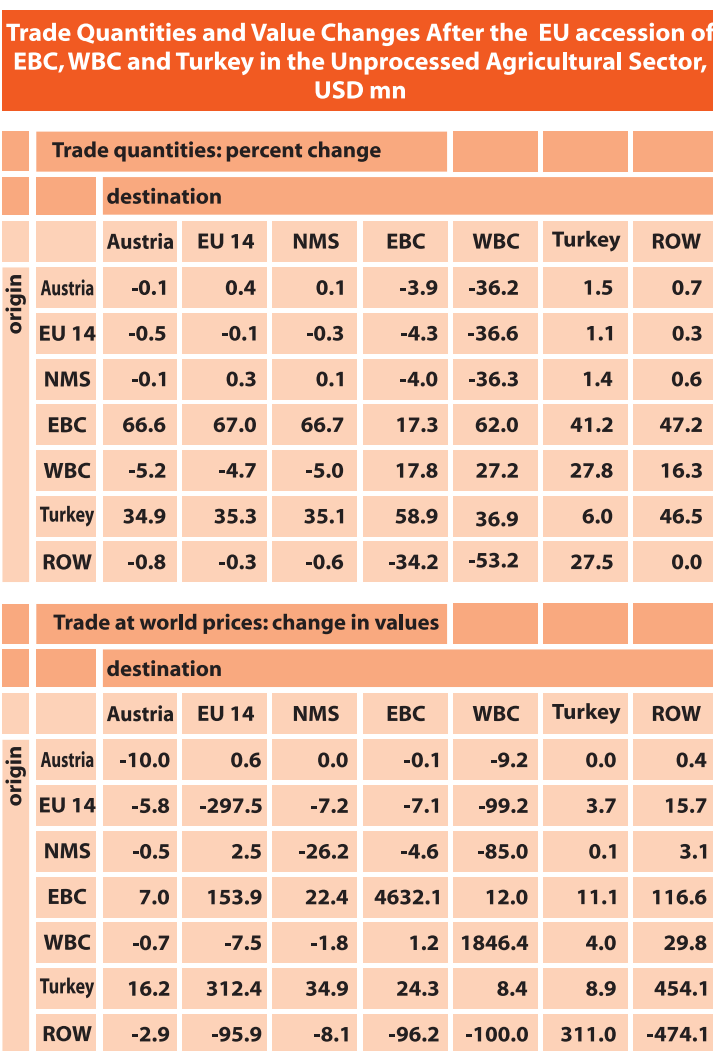

\section{Table 2}

self of the EBC and the WBC region with a plus of USD 4.6 bn and USD $1.8 \mathrm{bn}$, respectively. Unsurprisingly, WBC exports to the incumbent EU members do not increase, as these exports were not already facing tariff barriers before accession.

On the other side, Austria, the EU 14 and the NMS do not face any substantial changes in exports to the Balkans and Turkey, the sole exception being a reduction of exports to the West Balkans by about a third. Given the heavy increase of $28 \%$ of the WBC trade with self, incumbent EU exporters can't profit from the abolition of WBC tariff barriers. However, in absolute terms, this is not a significant loss. Austria, for instance, would reduce its exports of unprocessed agricultural goods to the WBC by only USD $9 \mathrm{mn}$. In total, for a country like Austria, the EU accession of the Balkans and Turkey has only a minor effect on the unprocessed agriculture sector. Total exports are estimated to fall by USD $8 \mathrm{mn}$, total imports increase by USD $13 \mathrm{mn}$ and domestic sales decrease by USD $10 \mathrm{mn}$.

In the case of the Balkan and Turkish EU accession effects on the processed agricultural sector, the results are quite similar, although of lower magnitude (see Table 3). All the countries and regions are expected to face a modest, positive two-digit USD mn net welfare effect. Only the West Balkans and Turkey might loose about USD $40 \mathrm{mn}$ and USD $45 \mathrm{mn}$, respectively. This is because in the first case the loss in tariff revenues is significant, and in the second the overall consumer price after liberalisation actually increases, making the consumer surplus is negative. This sector's output is expected to increase or at least stagnate in all the regions. The WBC and the EBC can generate by far the highest output increases with $12 \%$ and $6 \%$, respectively.

Again, these output increases are mostly due to a significant surge in intra-regional sales in both the EBC and WBC of USD 3.5 bn and USD 1.2 bn after liberalisation

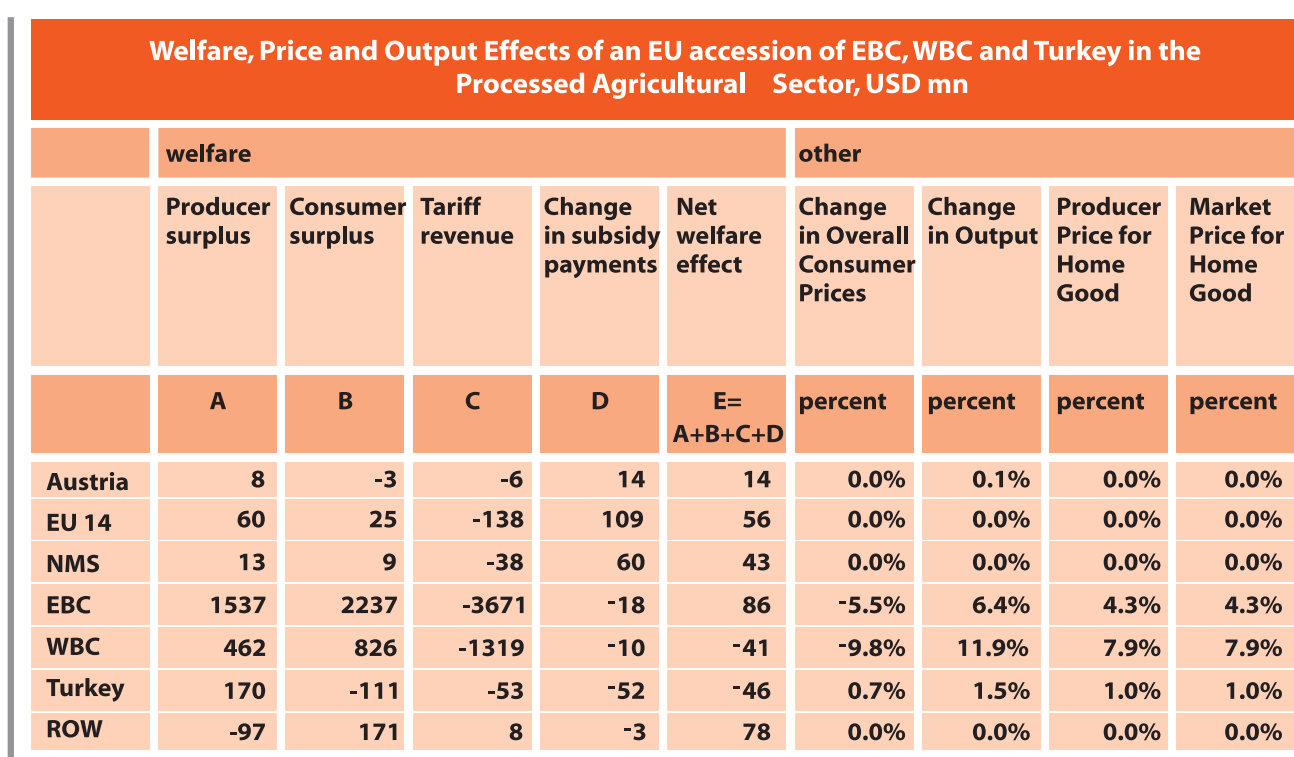

Table 3 
Trade Quantities and Value Changes After an EU accession of EBC, WBC and Turkey in the Processed Agricultural Sector, USD $\mathrm{mn}$

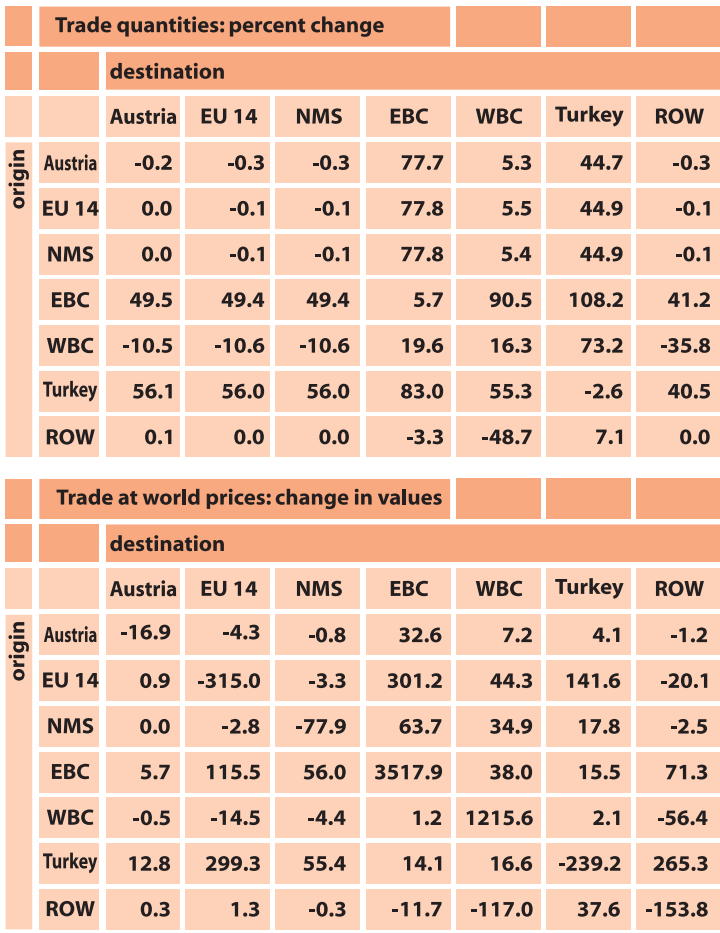

\section{Table 4}

(see Table 4). Otherwise it is the EBC and Turkey especially that can increase substantially their exports to the other regions, at least in relative terms. The incumbent EU members face only minor export changes except for the relative change in exports to the EBC and Turkey that are estimated to increase by almost $80 \%$ and $45 \%$ respectively. However, it has to be noted that an increase of Austrian exports to the EBC of $78 \%$ in real terms is related to an increase of some USD $33 \mathrm{mn}$ in world prices only. In total, Austria would experience an increase of exports of USD $38 \mathrm{mn}$, an increase of imports of USD $19 \mathrm{mn}$ and a decrease of domestic sales of processed agricultural goods of USD $17 \mathrm{mn}$.

One of the reasons for a more balanced result in the case of the processed agricultural sector as compared to the unprocessed agricultural sector is because here production subsidies are not relevant. In general it has to be said that the effects of an EU accession of the Balkans and Turkey are estimated to be only of a modest magnitude and will not affect both the processed and the unprocessed agricultural sector, especially in the incumbent EU member countries.

\subsection{Turkish devaluation}

In this simulation we analyse agricultural trade changes in a scenario where Turkey is assumed to devalue its real exchange rate by $10 \%$, while the other Balkan countries have a fixed exchange rate regime against the EU. Here we focus specifically on Turkey, as all the other Balkan countries have a de facto fixed exchange rate vis a vis the euro, a currency board, have even taken over the euro as legal tender or will enter the European Exchange Rate Mechanism soon. Apart from falling trade barriers, 'beggar-my-neighbour' exchange rate policy is often considered as a threat.

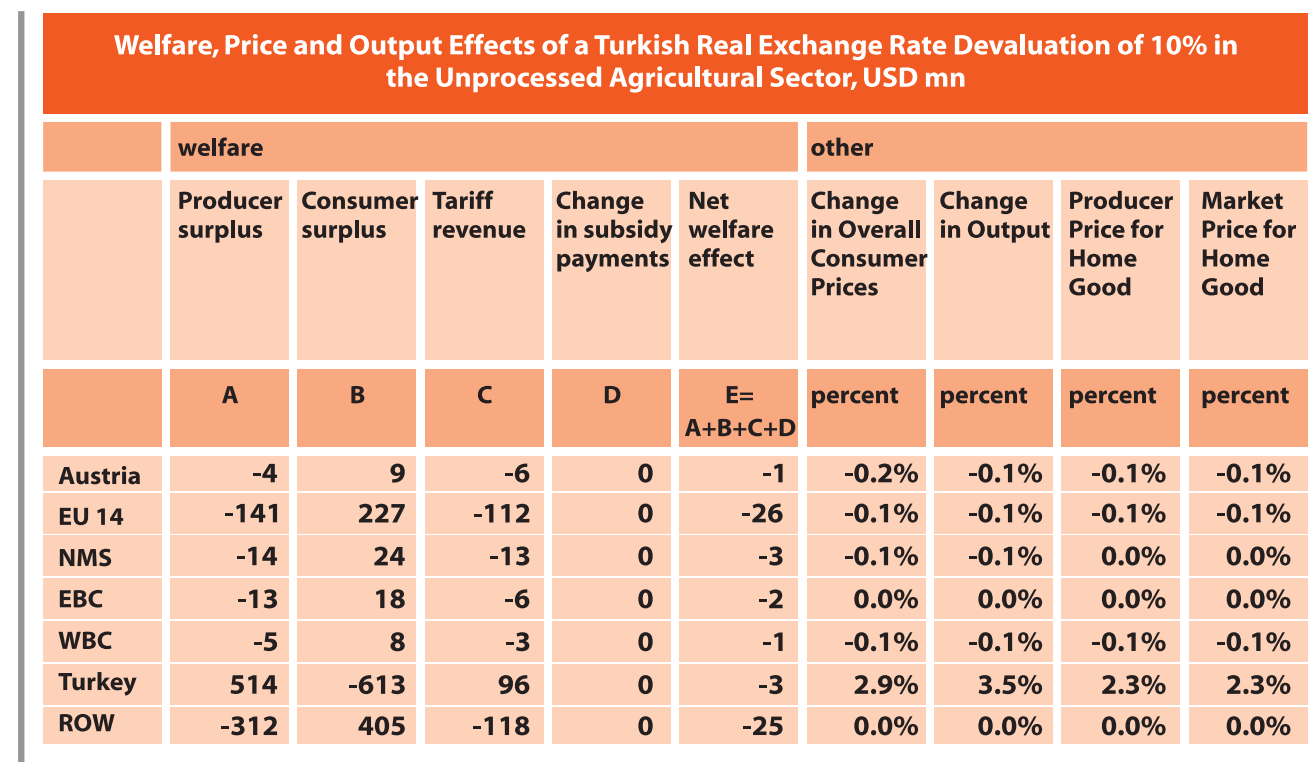

Table 5 


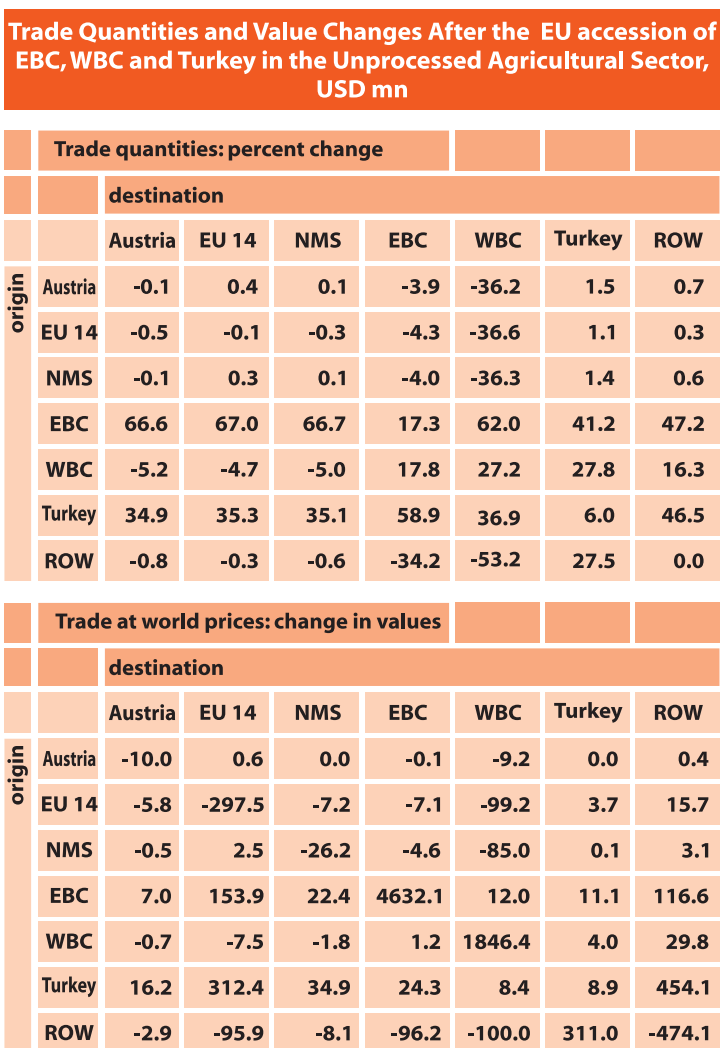

\section{Table 6}

Assuming that each measure of economic policy can be substituted by another with regard to its effects, we shall feed the GSIM instead of tariff rates with the rate of the initial real exchange rate undervaluation of Turkey and the final overvaluation of all the other regions of $10 \%$. From earlier research we know that a $10 \%$ real exchange rate devaluation could be triggered inter alia by a nominal exchange rate depreciation of about $65 \%$ (see Holzner 2006b). Thus we are checking for quite a substantial policy change.

As was done in the chapter before, we will again look separately at the unprocessed and processed agricultural sectors. For the unprocessed agricultural sector in the analysed regions we find hardly any net welfare effect from a $10 \%$ Turkish real exchange rate devaluation (see Table 5). Also, output changes are close to zero. Only Turkey itself can increase output by some 3.5\% after depreciation. Please note that in this case information on changes in tariff revenue is inappropriate and should be disregarded. With regard to relative changes in real trade flows we can observe a reduction of Turkish imports by close to $40 \%$ and an increase of Turkish exports by about 35\% (see Table 6). Most substantially, Turkish exports to the EU 14 are estimated to increase by USD $424 \mathrm{mn}$. Austia's total exports in the sector analysed would decrease by half a million USD only. Austrian imports would increase by USD $16 \mathrm{mn}$, and domestic sales would drop by about USD $10 \mathrm{mn}$.

Again, the simulation estimated for the processed agricultural sector behaves pretty similar. The net welfare effects of a Turkish devaluation are even less important than in the case of unprocessed agricultural goods (see Table 7). While the output of the other regions in the world does not change, Turkish output rises by some $2.6 \%$. Please note again that in this case information on changes in tariff revenue is inappropriate and should be disregarded.

Welfare, Price and Output Effects of a Turkish Real Exchange Rate Devaluation of $10 \%$ in the Processed Agricultural Sector, USD mn

\begin{tabular}{|c|c|c|c|c|c|c|c|c|c|}
\hline & \multicolumn{5}{|l|}{ welfare } & \multicolumn{4}{|l|}{ other } \\
\hline & $\begin{array}{l}\text { Producer } \\
\text { surplus }\end{array}$ & $\begin{array}{l}\text { Consumer } \\
\text { surplus }\end{array}$ & $\begin{array}{l}\text { Tariff } \\
\text { revenue }\end{array}$ & $\begin{array}{l}\text { Change } \\
\text { in subsidy } \\
\text { payments }\end{array}$ & $\begin{array}{l}\text { Net } \\
\text { welfare } \\
\text { effect }\end{array}$ & $\begin{array}{l}\text { Change } \\
\text { in Overall } \\
\text { Consumer } \\
\text { Prices }\end{array}$ & $\begin{array}{l}\text { Change } \\
\text { in Output }\end{array}$ & $\begin{array}{l}\text { Producer } \\
\text { Price for } \\
\text { Home } \\
\text { Good }\end{array}$ & $\begin{array}{l}\text { Market } \\
\text { Price for } \\
\text { Home } \\
\text { Good }\end{array}$ \\
\hline & A & B & C & D & $\begin{array}{c}E= \\
A+B+C+D\end{array}$ & percent & percent & percent & percent \\
\hline Austria & -3 & 5 & -2 & 0 & -1 & $0.0 \%$ & $0.0 \%$ & $0.0 \%$ & $0.0 \%$ \\
\hline EU 14 & -101 & 141 & -52 & 0 & -12 & $0.0 \%$ & $0.0 \%$ & $0.0 \%$ & $0.0 \%$ \\
\hline NMS & -16 & 23 & -10 & 0 & -2 & $0.0 \%$ & $0.0 \%$ & $0.0 \%$ & $0.0 \%$ \\
\hline EBC & -6 & 8 & -2 & 0 & 0 & $0.0 \%$ & $0.0 \%$ & $0.0 \%$ & $0.0 \%$ \\
\hline WBC & -3 & 5 & -3 & 0 & 0 & $-0.1 \%$ & $-0.1 \%$ & $0.0 \%$ & $0.0 \%$ \\
\hline Turkey & 292 & -363 & 54 & 0 & -16 & $2.2 \%$ & $2.6 \%$ & $1.7 \%$ & $1.7 \%$ \\
\hline ROW & -159 & 215 & -63 & 0 & -7 & $0.0 \%$ & $0.0 \%$ & $0.0 \%$ & $0.0 \%$ \\
\hline
\end{tabular}

Table 7 
Trade Quantities and Value Changes After a Turkish Real Exchange Rate Devaluation of $10 \%$ in the Processed Agricultural Sector, USD mn

\begin{tabular}{|l|r|r|r|r|r|r|}
\hline \multicolumn{3}{|c|}{ Trade quantities: percent change } \\
\hline \\
\hline
\end{tabular}

\section{Table 8}

When looking at the real trade flow changes we can observe a drop of Turkish imports of a bit more than $40 \%$ and an increase of Turkish exports of a bit less than $40 \%$ (see Table 8). In monetary terms, though, this is much less than in the case of the unprocessed agricultural goods trade. Turkish exports to the EU 14 are estimated to increase by some USD $200 \mathrm{mn}$. For Austria we find a reduction of total exports by some USD $4 \mathrm{mn}$ and an increase in total imports of processed agricultural goods by about USD 7 $\mathrm{mn}$. Austrian trade with self is expected to fall by more than USD $4 \mathrm{mn}$.

Taken together, these results indicate no dramatic changes as an effect of a massive Turkish currency devaluation. This is considering the fact that only Austrian output of processed agricultural goods is at a two digit USD bn level. Thus, for instance, an increase of USD 7 $\mathrm{mn}$ in imports seems to be rather negligible. However, it is true that, in relative terms, trade changes seem to be substantial.

\section{Conclusions}

In this research a partial equilibrium model was applied to the agricultural trade between the EU, the Balkans and
Turkey. This was done in order to measure the effects of an EU accession of the Balkans and Turkey. Most of the changes in welfare after a full liberalisation of agricultural trade between the Balkans and Turkey on the one hand, and the EU on the other can be expected in the accession countries themselves. It is estimated that incumbent EU members will be affected only to a minor extent.

The results of the simulation of a Turkish exchange rate devaluation are pointing in a similar direction. Turkish output and its trade balance would be improved to a certain extent. However, the other countries would not be affected very much.

In any case it should not be forgotten that all the results of this modelling have to be analysed with great caution, as they are generated with the help of a partial equilibrium model and not a general equilibrium model. A general equilibrium model could find additional second round effects.

Nevertheless, this research indicates that the incumbent EU members, including Austria, do not have to fear an EU accession of the Balkan countries and Turkey. The effects of liberalised agricultural trade seem to be marginal and even the exchange rate risk is not very high. $\square$. 


\section{References}

Fujita, M., Krugman, P., Venables, A. (2000), The Spatial Economy - Cities, Regions and International Trade, The MIT Press, Cambridge, Massachusetts, 2000.

Francois, J., Hall, K.,H. (2003), Global Simulation Analysis of Industry-Level Trade Policy, technical paper, Version 3.0: 21 April 2003, mimeo (World Bank).

Holzner, M. (2004), 'GSIM Measurement of the Costs of Protection in Southeast Europe', paper prepared for the project 'Measurement of the Costs of Protection in Southeast Europe' financed by the Jubiläumsfonds of the Oesterreichische Nationalbank, June 2004.

Holzner, M. (2006a), 'GSIM Measurement of the Effect of the SAA in BiH', EPRU Working Paper, No 4, March.

Holzner, M. (2006b), 'Real Exchange Rate Distortion in Southeast Europe', paper prepared for the 'Global Development Network Southeast Europe' (GDN SEE), financed by The World Bank, the Austrian Ministry of Finance and the Oesterreichische Nationalbank (Austrian Central Bank).

Lukas, Z., Pöschl, J. (2003), ,Bedrohung für Österreichs Landwirtschaft? - Szenarien zur Entwicklung der MOELandwirtschaft im europäischen und internationalen Verbund', The Vienna Institute for International Economic Studies (WIIW), Vienna, 2003.

Messerlin, P. (2001), Measuring the Cost of Protection in Europe, Institute for International Economics, Washington DC, September 2001. 